
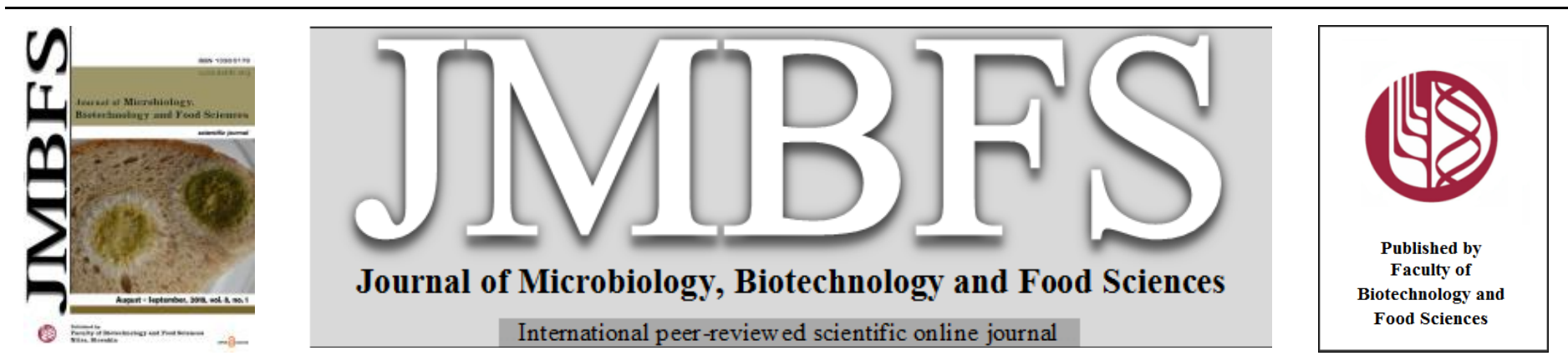

\title{
EXTRACTION OF POLYSACCHARIDES FROM OPUNTIA CACTUS FOR ITS POTENTIAL APPLICATION IN EDIBLE COATING TO IMPROVE THE SHELF LIFE OF CITRUS (KINNOW MANDARIN) FRUIT
}

\section{Sara Riaz ${ }^{1}$, M. Tauseef Sultan ${ }^{1}$, Muhammad Sibt-e-Abass ${ }^{*}{ }^{2}$, Muhammad Imran ${ }^{3}$ Rabia Shabir Ahmad ${ }^{4}$,Muhammad Bilal Hussain ${ }^{4}$, Mohammad Ali Shariati ${ }^{5}$, Inna Sergeevna Kosenko ${ }^{6}$, Natalia Leonidovna Kleymenova ${ }^{7}$, Galina Nikolaevna Egorova ${ }^{8}$}

\section{$\operatorname{Address(es):~}$}

${ }^{1}$ Institute of Food Science and Nutrition, FAST, Bahauddin Zakariya University, Multan.

${ }^{2}$ Sahiwal Campus, Government College University, Faisalabad.

${ }^{3}$ University Institute of Diet and Nutritional Sciences, The University of Lahore, Pakistan.

${ }^{4}$ Institute of Home and Food Sciences, Government College University, Faisalabad.

${ }^{5}$ Laboratory of Biocontrol and Antimicrobial Resistance, Orel State University named after I.S. Turgenev, Orel, 302026, Russia, +7(4862) 751-318.

${ }^{6}$ Candidate of technical sciences, associate professor of quality management and machine-building technologies department, Voronezh state university of engineering technologies, Voronezh, Russia.

${ }^{7}$ Candidate of technical sciences, associate professor of quality management and machine-building technologies department, Voronezh state university of engineering technologies, Voronezh, Russia.

${ }^{8}$ Candidate of pedagogic sciences, associate professor of industrial ecology, equipment of chemical and petrochemical industries department, Voronezh state university of engineering technologies, Voronezh, Russia.

*Corresponding author: tauseefsultan@ bzu.edu.pk

doi: 10.15414/jmbfs.2018.8.1.745-750

\section{ARTICLE INFO}

Received 1.6. 2018

Revised 22. 6. 2018

Accepted 24. 7. 2018

Published 1. 8. 2018

Regular article open $\odot$ access

\begin{abstract}
Fruits and vegetables are subjected to post-harvest losses due to high moisture contents along with other physiological factors. Among various measure to control loses, development of edible coatings has been an imperative and innovative technique to achieve the desired goal. Opuntia cactus, a xerotrophyte, plant contains appreciable amount of polysaccharides thus can be utilized in edible coating formation. The mandate of present study was to extract polysaccharides from cactus for development of edible coatings for their potential applications on citrus fruits. For the purpose, various concentrations of extracted cactus polysaccharides were used to develop edible coatings. These coating were applied on citrus fruits (Kinnow mandarin) which were then stored for period of 35 days. The results indicated that the maximum moisture was observed in $\mathrm{T}_{3}$ (2\% cactus polysaccharides) i.e. $86.94 \pm 2.10 \%$. The maximum value for $\mathrm{pH}$ of coated citrus was found in $\mathrm{T}_{1}(3.19 \%$ cactus polysaccharides $)$ as $3.19 \pm 0.02 \%$. Conclusively, as the demand of fresh looking fruits and vegetables is increasing due to the awareness among the masses, edible coatings using cactus polysaccharides can play an imperative role in increasing the shelf life along with retaining the quality of various commodities.
\end{abstract}

Keywords: Citrus, Edible coating, Cactus, Polysaccharides, Post-harvest losses

\section{INTRODUCTION}

Fruits and vegetables are important components of human diet which provide vital nutrients required to boost the health of individuals. Some fruits and vegetables continue their physiological activity even after harvesting thus they are more susceptible to deterioration during storage and transportation resulting in undesirable changes in composition, flavor, appearance and their consumer acceptability (Hodges $\boldsymbol{e t}$ al., 2011). Being perishable commodities, they are more susceptible to post-harvest losses. Currently, these losses are around 25-40\% of total produce (Musasa et al., 2013).

Various techniques to curtail these losses were developed and some of them find potential applications of low temperature, irradiation, and edible coating. Among these, edible coating has gained more importance nowadays. Edible films and coating usually applied to improve the gas \& moisture barrier properties. Mechanical features, sensory appraisal, convenience in use and protection against microbial pathogens are its additional benefits. Edible coating is a thin layer of materials applied as a semi-liquid at the outer surface of the commodity by spraying, dipping or brushing. There are different types of coatings based on the material used and amongst polysaccharides based edible coatings are gaining ore popularity. The polysaccharides based edible coatings are hydrophilic in nature thus provide strong hydrogen bonding (Yahia et al., 2004; Abeeret al., 2013).

Citrus being most commonly cultivated tree in the world, with total global production of 72.8 million metric tons in 2005/2006 due to its fruits widely used all around the world. Citrus have a variety of nutrients such as vitamin $\mathrm{C}$, vitamin A (e.g. beta-carotene, zeaxanthin), folate and fiber as well as many non-nutrient phytochemicals such as flavonoids, triterpenes and phenol acids (Eckert $\boldsymbol{e t}$ al., 1989).

Sadly, most of the fruits produced are wasted due to pre/post-harvest damages and the natural ripening enzymes which reduce its shelf-life. Such fruits can be preserved by the use of edible coatings thus maximizing the benefits and minimizing the waste produced. Previously, important polysaccharides used in this type of coatings are starches and celluloses present in plants. However, some of wild plants grown in different parts of the globe contain higher amounts of complex polysaccharides. In Pakistan more than 6000 species of wild plants are reported. One of these is Opuntia cactus, a xerotrophyte and native to arid and semi-arid zones. Plants like these can be utilized to protect highly perishable fruits and vegetables, allowing us to extend the shelf-life and availability of fruits like citrus. Thus present research has been designed to investigate the option of extraction of polysaccharides from wild Opuntia cactus plant for the preparation of edible coating to improve the shelf life of citrus fruits along with marinating the quality over a longer period of time.

\section{MATERIAL AND METHODS}

Extraction of Polysaccharides from Cactus

\section{Sample preparation}

Fresh cactus $(1000 \mathrm{~g})$ was taken and thorns were removed. Samples were washed properly then cut into small pieces and spread on the sheet for some days until 
sample was ready for grinding purpose. After grinding, sieving of grounded sample was done and powder was further used for polysaccharides extraction.

\section{Extraction procedure}

The extraction of polysaccharides from the cactus was done by using hot water as a medium; $100 \mathrm{~g}$ sample was added in $1000 \mathrm{~mL}$ hot water. Firstly, three different buffer solutions $(7,4$, and 9$)$ were used for calibration of $\mathrm{pH}$ meter. $\mathrm{pH}$ of sample was maintained at 10 into half boiled water $(500 \mathrm{ml})$ and then placed for $5 \mathrm{~h}$ without shaking. Precipitate was separated from supernatant. After that supernatant put into refrigerator overnight then precipitate was separated and dried in hot air oven at temperature $105^{\circ} \mathrm{C}$ for $12 \mathrm{hrs}$. This dried extract was called polysaccharide. The final yield of extract at $\mathrm{pH} 10$ was $10 \mathrm{~g}$. At $\mathrm{pH} 9$ polysaccharides were extracted by following above procedure but sample weight was $50 \mathrm{~g}$ in $500 \mathrm{~mL}$ half boiled water with final yield of $5 \mathrm{~g}$. Same extract was prepared by maintaining $\mathrm{pH} 8$ with final extraction of $5 \mathrm{~g}$.

Extraction rate $(\%)=($ polysaccharides weight - raw material weight $) \times 100$

\section{Preparation of Edible Coating}

Edible coating was prepared by complete mixing of polysaccharides extract (1g), acetic acid (1g), ascorbic acid $(2 \mathrm{~g})$, citric acid $(1 \mathrm{~g})$, glycerol $(1.5 \mathrm{~g})$, sunflower oi (0.025) and distilled water (1ooml) for treatment 2 . Three different concentrations of these edible coatings were prepared.

Table 1 Different concentration of Polysaccharides based coatings

T0 $\quad$ T1

Chemicals

\begin{tabular}{|c|c|c|c|c|}
\hline & Control & 0.5\% polysaccharide & $1 \%$ polysaccharide & $2 \%$ polysaccharide \\
\hline Polysaccharides & - & $0.5 \mathrm{~g}$ & $1 \mathrm{~g}$ & $2 \mathrm{~g}$ \\
\hline Glycerol & - & $1.5 \mathrm{~g}$ & $1.5 \mathrm{~g}$ & $1.5 \mathrm{~g}$ \\
\hline Sunflower oil & - & $0.025 \mathrm{~g}$ & $0.025 \mathrm{~g}$ & $0.025 \mathrm{~g}$ \\
\hline Ascorbic acid & - & $2 \mathrm{~g}$ & $2 \mathrm{~g}$ & $2 \mathrm{~g}$ \\
\hline Acetic acid & - & $1 \mathrm{~g}$ & $1 \mathrm{~g}$ & $1 \mathrm{~g}$ \\
\hline Distilled water & - & $100 \mathrm{~mL}$ & $100 \mathrm{~mL}$ & $100 \mathrm{~mL}$ \\
\hline Citric acid & - & $1 \mathrm{~g}$ & $1 \mathrm{~g}$ & $1 \mathrm{~g}$ \\
\hline
\end{tabular}

\section{Application of edible coating on citrus}

\section{Sample preparation}

Citrus from commercial orchards were selected and used in the experiments before any postharvest treatment was applied. Citrus fruits were selected on the basis of size, color and absence of external injuries. The fruits were stored up to 1 week at temperature of $5^{\circ} \mathrm{C}$ and relative humidity $90 \%$ before application of coating. Before each experiment the fruits were randomly washed with fresh water and allowed to air-dry at room temperature.

\section{Surface preparation of citrus}

The primary purpose of surface preparation was to remove all contaminants that would hinder proper coating adhesion.

\section{Application of edible coating}

Citrus fruits were dipped for the time interval of $1 \mathrm{~min}$ in the film forming dispersions. Afterwards; they were dried at room temperature for 2-4 h then stored in the cooling environment. The formulation of edible coating for treatment 1 , Extract $0.5 \mathrm{~g}$, addition of acetic acid, ascorbic acid $2 \mathrm{~g}$, citric acid $1 \mathrm{~g}$ which were act as a antimicrobial. Glycerol 1.5 , sunflower oil $0.025 \mathrm{~g}$ and distilled water $100 \mathrm{ml}$. All above ingredients were mixed thoroughly and applied on fruit. The formulation of edible coating for treatment 2, Extract $1 \mathrm{~g} .1 \mathrm{~g}$ acetic acid, $2 \mathrm{~g}$ ascorbic acid, citric acid, glycerol $1.5 \mathrm{~g}$, sunflower oil $0.025 \mathrm{~g}$ and distilled water $100 \mathrm{ml}$. These ingredients were mixed and then applied on citrus. The formulation of edible coating for treatment 3, Extract of polysaccharides $2 \mathrm{~g}$, $1 \mathrm{~g}$ of acetic acid, $2 \mathrm{~g}$ of ascorbic acid, $1 \mathrm{~g}$ of citric acid, glycerol1.5, oil $0.025 \mathrm{~g}$ and distilled water $100 \mathrm{ml}$ were mixed and formed edible coating. For comparing purpose standard of fruits was also taken into the cooling environment analyzed at zero stage and after every 15 days. The storage period was 15, 25 and 35 days for edible coated citrus.

\section{Proximate analysis of citrus}

The edible coated citrus samples were analyzed for, moisture, ash content and crude fiber according to their respective methods described in AACC (2000).

\section{Physical parameters of citrus}

\section{pH of citrus}

The $\mathrm{pH}$ of citrus fruit was determined by preparation of required citrus juice quantity in $100 \mathrm{ml}$ beaker. With the help of digital $\mathrm{pH}$ meter following the procedure as, $\mathrm{pH}$ meter electrodes were standardized with 4,7 and 9 buffer solution. $\mathrm{pH}$ meter device is ready for taking the $\mathrm{pH}$ reading of citrus when $\mathrm{pH}$ meter gave arrow head signal on slide. $\mathrm{pH}$ electrode was put into the beaker as the tip of the electrode was covered and note the $\mathrm{pH}$ reading of citrus juice.

\section{Acidity of citrus}

The total acidity of citrus was determined by using the method described by Kirk and Sawyer (1999). About $15 \mathrm{~mL}$ of citrus juice was taken in 3 conical flasks and 1 to 2 drops of phenolphthalein were added in each flask as indicator. Then 20 $\mathrm{mL}$ of distilled water was added for dilution purpose and $0.1 \mathrm{~N} \mathrm{NaOH}$ was used to titrate against it. $\mathrm{NaOH}$ volume was noted that was used for titration process. The titratable acidity was determined by following formula: Total acidity $\%=($ Liter $\times$ Y $/$ Volume of sample $) \times 100$

Where,

$\mathrm{Y}=$ Mol. wt. of citric acid $/ 1000 \times 10$

\section{Sensory evaluation}

The coated citrus fruits were evaluated for taste, color, flavor, texture and overall acceptability by 9 -point hedonic score system $(9=$ like extremely; $1=$ dislike extremely) by panel of judges from Department of Food Science and Technology Bahauddin Zakariya University according to the procedure described by Meilgaard et al. (2007). They also conducted organoleptic analysis which was based on flavor, firmness, overall acceptability and color of commodity after specific interval as compared to control sample.

\section{Statistical analysis}

The data of each parameter was obtained by applying completely randomized design (CRD). Levels of significance $(P \leq 0.05 \& \mathrm{P} \leq 0.01)$ were determined using 2 -factor factorial under CRD by following the principles outlined by Steel et al. (1997). Significant ranges were further compared using Duncan Multiple Range (Steel et al., 1997).

\section{RESULTS AND DISCUSSION}

\section{Moisture content of citrus}

The maximum moisture (Table 2)was observed in $\mathrm{T}_{3} \quad(86 \%$ cactus polysaccharides) as $86.94 \pm 2.10 \mathrm{ab}$ followed by $\mathrm{T}_{2} \quad(85.46 \%$ cactus polysaccharides) as $85.47 \pm 2.12 \mathrm{ab}$.However, the treatments $\mathrm{T}_{1}$ (84\% cactus polysaccharides) and $\mathrm{T}_{0}$ (control) exhibited the value for moisture as $84.32 \pm 1.56 \mathrm{bc}$ and $83.26 \pm 1.43$ crespectively. Over the storage, decrease in the moisture content was noticed that varied from $89.83 \pm 2.78 \%$ at 15 days to $85.35 \pm 1.40 \%$ at 25 days .However, at the termination of 35 days study, moisture was $77.77 \pm 0.51 \%$. Likewise, among treatments, a similar decrease in moisture was reported with the course of storage at declined from $87.22 \pm 1.72 \%$ and $91.49 \pm 2.71 \%$ at 15 days and $85.95 \pm 1.86 \%$ and $86.79 \pm 1.77 \%$ at 25 days in $\mathrm{T}_{2}$ and $\mathrm{T}_{3}$, respectively. The maximum decrease in moisture was found in $\mathrm{T}_{0}$ (control) as $90.01 \pm 1.60 \%$ at 15 days to $83.93 \pm 0.95 \%$ and $75.84 \pm 1.75 \%$ at 25 days and 35 days respectively. Instant research is in accordance with the work of Mohebbi $\boldsymbol{e t}$ al. (2012). In another study, Al-Juhaimi et al. (2012) worked on coating combination involving polysaccharides to produce edible films and coatings They deduced that coatings decreased fruit weight \& moisture loss, decay incidence. 
Table 2 Effects of edible coatings (treatments) and storage intervals on moisture contents of citrus

\begin{tabular}{lcccc}
\hline \multirow{2}{*}{ Treatments } & \multicolumn{3}{c}{ Storage } & Means (Treatments) \\
\cline { 2 - 4 } & $\mathbf{1 5}$ days & $\mathbf{2 5}$ days & 35 days & \\
\hline $\mathrm{T}_{0}$ & $90.01 \pm 1.60$ & $83.93 \pm 0.95$ & $75.84 \pm 1.75$ & $83.26 \pm 1.43 \mathrm{c}$ \\
\hline $\mathrm{T}_{1}$ & $89.83 \pm 2.78$ & $85.35 \pm 1.40$ & $77.77 \pm 0.51$ & $84.32 \pm 1.56 \mathrm{bc}$ \\
\hline $\mathrm{T}_{2}$ & $87.22 \pm 1.72$ & $85.95 \pm 1.86$ & $83.23 \pm 2.78$ & $85.47 \pm 2.12 \mathrm{ab}$ \\
\hline $\mathrm{T}_{3}$ & $91.49 \pm 2.71$ & $86.79 \pm 1.77$ & $82.55 \pm 1.82$ & $86.94 \pm 2.10 \mathrm{a}$ \\
\hline Means (Storage) & $89.64 \pm 2.20 \mathrm{a}$ & $85.51 \pm 1.50 \mathrm{~b}$ & $79.85 \pm 1.72 \mathrm{c}$ & \\
\hline $\mathrm{T}_{0}:$ Control, $\mathrm{T}_{1}:\left(84.31 \%\right.$ cactus polysaccharides), $\mathrm{T}_{2}:(85.46 \%$ cactus & polysaccharides), $\mathrm{T}_{3}:(86.94 \%$ cactus polysaccharides)
\end{tabular}

$\mathrm{T}_{0}$ : Control, $\mathrm{T}_{1}:$ ( $84.31 \%$ cactus polysaccharides), $\mathrm{T}_{2}:\left(85.46 \%\right.$ cactus polysaccharides), $\mathrm{T}_{3}:(86.94 \%$ cactus polysaccharides $)$

\section{Crude fiber}

The mean values (Table 3) regarding crude fiber depicted non-significant variations among treatments while there was a significant variation with respect to storage. The maximum crude fiber was observed in $\mathrm{T}_{0}$ (Control) as $4.96 \pm 0.16 \%$ followed by $\mathrm{T}_{2}\left(1.0 \%\right.$ cactus polysaccharides) and $\mathrm{T}_{3}(2.0 \%$ cactus polysaccharides)as $4.83 \pm 0.12 \%$ and $4.83 \pm 0.08 \%$, respectively. However, the lowest value was observed for $\mathrm{T}_{1}(0.5 \%$ cactus polysaccharides $)$ as $4.82 \pm 0.10 \%$. Over the storage, increase in crude fiber content was noticed that varied from $4.62 \pm 0.10 \%$ at $15^{\text {th }}$ day to $4.90 \pm 0.13$ at $25^{\text {th }}$ day. However, at the termination of
35 days study, crude fiber was $5.07 \pm 0.12 \%$. Likewise, among treatments, a similar increase in crude fiber was reported with the course of storage that increased from $4.71 \pm 0.06 \%$ and $4.57 \pm 0.11 \%$ at $15^{\text {th }}$ day to $4.78 \pm 0.12 \%$ and $4.90 \pm 0.16 \%$ at $25^{\text {th }}$ day in $\mathrm{T}_{3}(2.0 \%$ cactus polysaccharides $)$ and $\mathrm{T}_{2}(1.0 \%$ cactus polysaccharides), respectively. The maximum increase in crude fiber was found in $\mathrm{T}_{0}$ (Control) as $4.57 \pm 0.14 \%$ at $15^{\text {th }}$ day to $5.09 \pm 0.18 \%$ and $5.23 \pm 0.17 \%$ at $25^{\text {th }}$ and $35^{\text {th }}$ day, respectively. Instant research is in accordance with the work of Mohebbi et al. (2012)and Al-Juhaimi et al. (2012).

Table 3 Effects of edible coatings (treatments) and storage intervals on crude fiber content of citrus

\begin{tabular}{lcccc}
\hline \multirow{2}{*}{ Treatments } & \multicolumn{3}{c}{ Storage } & \multirow{2}{*}{ Means (Treatments) } \\
\cline { 2 - 4 } & 15 days & 25 days & 35 days & $4.96 \pm 0.16 \mathrm{a}$ \\
\hline $\mathrm{T}_{0}$ & $4.57 \pm 0.14$ & $5.09 \pm 0.18$ & $5.23 \pm 0.17$ & $4.82 \pm 0.10 \mathrm{~b}$ \\
\hline $\mathrm{T}_{1}$ & $4.64 \pm 0.10$ & $4.82 \pm 0.06$ & $5.01 \pm 0.13$ & $4.83 \pm 0.12 \mathrm{~b}$ \\
\hline $\mathrm{T}_{2}$ & $4.57 \pm 0.11$ & $4.90 \pm 0.16$ & $5.01 \pm 0.09$ & $4.83 \pm 0.08 \mathrm{~b}$ \\
\hline $\mathrm{T}_{3}$ & $4.71 \pm 0.06$ & $4.78 \pm 0.12$ & $5.01 \pm 0.08$ & \\
\hline Means (Storage) & $4.62 \pm 0.10 \mathrm{c}$ & $4.90 \pm 0.13 \mathrm{~b}$ & $5.07 \pm 0.12 \mathrm{a}$ & \\
\hline $\mathrm{T}_{0}:$ Control, $\mathrm{T}_{1}:\left(4.82 \%\right.$ cactus polysaccharides), $\mathrm{T}_{2}:\left(4.82 \%\right.$ cactus polysaccharides), $\mathrm{T}_{3}:(4.83 \%$ cactus polysaccharides)
\end{tabular}

\section{Ash content of citrus}

The maximum value for ash contents of coated citrus (Table 4) was found in $\mathrm{T}_{1}$ ( $2.56 \%$ cactus polysaccharides) as $2.56 \pm 0.07 \mathrm{~b}$ followed by $\mathrm{T}_{3}$ (2.51 cactus polysaccharides) as $2.52 \pm 0.05 \mathrm{~b}$. Moreover, treatments $\mathrm{T}_{2}(2.51 \%$ cactus polysaccharides) and $\mathrm{T}_{0}$ (Control) showed ash contents values $2.51 \pm 0.05 \mathrm{~b}$ and $2.62 \pm 0.05 \mathrm{a}$, respectively. Over the storage, decrease in ash contents was noticed ranging from $2.51 \pm 0.05 \mathrm{~b}$ at initiation to $2.60 \pm 0.06 \mathrm{a}$ at termination of the trial Likewise, among treatments a systematic decrease in the ash contents was noticed during storage. Among treatments, $\mathrm{T}_{3}(2.51 \%$ cactus polysaccharides) indicated a gradual decrease in the ash contents from $2.48 \pm 0.04$ to $2.53 \pm 0.06$ and
$2.55 \pm 0.05$ at $25^{\text {th }}$ and $35^{\text {st }}$ day, respectively. Similarly, for treatments $T_{2}$ and $T_{1}$ variations in ash contents were $2.51 \pm 0.06$ to $2.49 \pm 0.02$ and $2.55 \pm 0.05$ to $2.55 \pm 0.08$ at $15^{\text {th }}$ to $25^{\text {st }}$ day, respectively. The maximum decrease in ash contents was observed for $\mathrm{T}_{\circ}$ (Control) as $2.49 \pm 0.05$ to $2.74 \pm 0.03$ at initiation to termination, respectively.

The findings of present research work are in agreement with the findings of Fan et al. (2009). Earlier, Vargas et al. (2009) worked on chitosan based edible coatings combined with oleic acid to preserve the quality of strawberry. They inferred that physicochemical properties, fungal decay and respiration rates of coated fruit were significantly addressed by coating applications.

Table 4 Effects of edible coatings (treatments) and storage intervals on ash contents (dry matter basis) of citrus

\begin{tabular}{lcccc}
\hline \multirow{2}{*}{ Treatments } & \multicolumn{3}{c}{ Storage } & \multirow{2}{*}{ Means (Treatments) } \\
\cline { 2 - 4 } & 15 days & 25 days & 35 days & $2.62 \pm 0.05 \mathrm{a}$ \\
\hline $\mathrm{T}_{0}$ & $2.49 \pm 0.05$ & $2.64 \pm 0.07$ & $2.74 \pm 0.03$ & $2.56 \pm 0.07 \mathrm{~b}$ \\
\hline $\mathrm{T}_{1}$ & $2.55 \pm 0.05$ & $2.55 \pm 0.08$ & $2.58 \pm 0.09$ & $2.51 \pm 0.05 \mathrm{~b}$ \\
\hline $\mathrm{T}_{2}$ & $2.51 \pm 0.06$ & $2.49 \pm 0.02$ & $2.53 \pm 0.06$ & $2.52 \pm 0.05 \mathrm{~b}$ \\
\hline $\mathrm{T}_{3}$ & $2.48 \pm 0.04$ & $2.53 \pm 0.06$ & $2.55 \pm 0.05$ & \\
\hline Means (Storage) & $2.51 \pm 0.05 \mathrm{~b}$ & $2.55 \pm 0.06 \mathrm{a}$ & $2.60 \pm 0.06 \mathrm{a}$ & \\
\hline
\end{tabular}

$\mathrm{T}_{0}$ : Control, $\mathrm{T}_{1}:$ ( $2.56 \%$ cactus polysaccharides), $\mathrm{T}_{2}:$ ( $2.51 \%$ cactus polysaccharides), $\mathrm{T}_{3}:(2.51 \%$ cactus polysaccharides $)$

\section{pH of citrus}

The maximum value for $\mathrm{pH}$ of coated citrus (Table 5) was found in $\mathrm{T}_{1}(3.19 \%$ cactus polysaccharides) as $3.19 \pm 0.02 \mathrm{~b}$ followed by $\mathrm{T}_{3} \quad(2.95 \%$ cactus polysaccharides $)$ as $2.95 \pm 0.04 \mathrm{c}$. . Moreover, treatments $\mathrm{T}_{2}(2.98 \%$ cactus polysaccharides) and $\mathrm{T}_{0}$ (Control) showed $\mathrm{pH}$ values $2.99 \pm 0.05 \mathrm{c}$ and $3.36 \pm 0.03 \mathrm{a}$ respectively. Over the storage of citrus the mean is $2.74 \pm 0.02 \mathrm{c}$ and $1.60 \pm 0.03 \mathrm{~b}$ at 15 and 25 days .respectively at 35 days the overall mean
The findings of instant research work are in agreement with the findings of Fan et al. (2009). They concluded that coating application resulted in restricting the rise in $\mathrm{pH}$ of coated strawberry. In another attempt Tapia et al. (2008) concluded that alginate based coatings resulted in improved water vapor resistance, controlled gaseous exchange and maintained overall quality of the fruit.

Table 5 Effects of edible coatings (treatments) and storage intervals on $\mathrm{pH}$ of citrus

\begin{tabular}{lcccc}
\hline \multirow{2}{*}{ Treatments } & \multicolumn{3}{c}{ Storage } & \multirow{2}{*}{ Means (Treatments) } \\
\cline { 2 - 4 } & $\mathbf{1 5}$ days & $\mathbf{2 5}$ days & 35 days & $3.36 \pm 0.03 \mathrm{a}$ \\
\hline $\mathrm{T}_{0}$ & $2.78 \pm 0.01$ & $3.37 \pm 0.03$ & $3.95 \pm 0.06$ & $3.19 \pm 0.02 \mathrm{~b}$ \\
\hline $\mathrm{T}_{1}$ & $2.87 \pm 0.01$ & $3.11 \pm 0.03$ & $3.60 \pm 0.03$ & $2.99 \pm 0.05 \mathrm{c}$ \\
\hline $\mathrm{T}_{2}$ & $2.67 \pm 0.04$ & $2.95 \pm 0.08$ & $3.34 \pm 0.04$ & $2.95 \pm 0.04 \mathrm{c}$ \\
\hline $\mathrm{T}_{3}$ & $2.64 \pm 0.01$ & $3.01 \pm 0.06$ & $3.21 \pm 0.04$ & \\
\hline Means (Storage) & $2.74 \pm 0.02 \mathrm{c}$ & $3.11 \pm 0.05 \mathrm{~b}$ & $3.53 \pm 0.04 \mathrm{a}$ & \\
\hline $\mathrm{T}_{0}:$ Control, $\mathrm{T}_{1}:\left(3.19 \%\right.$ cactus polysaccharides), $\mathrm{T}_{2}:\left(2.98 \%\right.$ cactus polysaccharides), $\mathrm{T}_{3}:(2.95 \%$ cactus polysaccharides)
\end{tabular}

\section{Acidity of citrus}

It is observed that the maximum value for acidity of edible coated citrus (Table6) was recorded in $\mathrm{T}_{1}$ (1.59\% cactus polysaccharides) as $1.59 \pm 0.02 \mathrm{~b}$ trailed by $\mathrm{T}_{3}$ (1.69\% cactus polysaccharides) and $\mathrm{T}_{2}(1.70 \%$ cactus polysaccharides) as $1.69 \pm 0.04 \mathrm{a}$ and $1.70 \pm 0.05 \mathrm{a}$, respectively. However, the lowest values for the trai were observed in $\mathrm{T}_{\mathrm{o}}$ (Control) as $1.51 \pm 0.03 \mathrm{c}$. During storage, a systematic increase in values for the trait was noticed as $1.83 \pm 0.04 \mathrm{a}$ at initiation that increased considerably to $1.60 \pm 0.03 \mathrm{~b}$ and $1.43 \pm 0.02 \mathrm{c}$ at $25^{\text {th }}$ and $35^{\text {st }}$ day, respectively.

Findings of the instant research are in corroboration with the work of Velickova et al. (2013) who used soy based edible coatings to extend shelf life of strawberries at controlled climate chamber. 
Table 6 Effects of edible coatings (treatments) and storage intervals on acidity of citrus

\begin{tabular}{lcccc}
\hline \multirow{2}{*}{ Treatments } & \multicolumn{3}{c}{ Storage } & \multirow{2}{*}{ Means (Treatments) } \\
\cline { 2 - 4 } & $\mathbf{1 5}$ days & $\mathbf{2 5}$ days & 35 days & \\
\hline $\mathbf{T}_{\mathbf{0}}$ & $1.76 \pm 0.03$ & $1.45 \pm 0.04$ & $1.30 \pm 0.02$ & $1.51 \pm 0.03 \mathrm{c}$ \\
\hline $\mathbf{T}_{\mathbf{1}}$ & $1.81 \pm 0.02$ & $1.59 \pm 0.04$ & $1.38 \pm 0.01$ & $1.59 \pm 0.02 \mathrm{~b}$ \\
\hline $\mathbf{T}_{\mathbf{2}}$ & $1.88 \pm 0.06$ & $1.71 \pm 0.04$ & $1.52 \pm 0.04$ & $1.70 \pm 0.05 \mathrm{a}$ \\
\hline $\mathbf{T}_{\mathbf{3}}$ & $1.89 \pm 0.06$ & $1.66 \pm 0.02$ & $1.53 \pm 0.03$ & $1.69 \pm 0.04 \mathrm{a}$ \\
\hline Means (Storage) & $1.83 \pm 0.04 \mathrm{a}$ & $1.60 \pm 0.03 \mathrm{~b}$ & $1.43 \pm 0.02 \mathrm{c}$ & \\
\hline $\mathbf{T}_{2}$ Connnnnn
\end{tabular}

$\mathrm{T}_{0}$ : Control, $\mathrm{T}_{1}$ : (1.59\% cactus polysaccharides), $\mathrm{T}_{2}$ : (1.70\% cactus polysaccharides), $\mathrm{T}_{3}:(1.69 \%$ cactus polysaccharides $)$

\section{Color}

Means regarding sensory color of edible coated citrus (Table 7) revealed significant variations among treatments and storage. The maximum panelist scores were assigned to treatment $\mathrm{T}_{3}(2.0 \%$ cactus polysaccharides) as $7.80 \pm 0.16$ trailed by $\mathrm{T}_{2}(1.0 \%$ cactus polysaccharides $)$ and $\mathrm{T}_{1}(0.5 \%$ cactus polysaccharides $)$ as $7.10 \pm 0.21$ and $6.77 \pm 0.25$, respectively. Whilst $\mathrm{T}_{0}$ (Control) was at par with a score of $6.33 \pm 0.16$. Moreover, there was observed a gradual decline in the scores for the trait with storage with $\mathrm{T}_{0}$ score declined from from $8.30 \pm 0.23$ to $5.90 \pm 0.12$ and $4.80 \pm 0.13$ at $15^{\text {th }}, 25^{\text {th }}$ and $35^{\text {th }}$ day, respectively. Likewise, for $\mathrm{T}_{1}$
andT $T_{2}$ panelist ratings for the trait were reported to lower from $7.80 \pm 0.26$ to $5.80 \pm 0.15$ and $8.40 \pm 0.30$ to $5.90 \pm 0.18$ at $15^{\text {th }}$ to $35^{\text {th }}$ day, respectively. For treatment $\mathrm{T}_{3}$, panelist ratings lowered from $8.80 \pm 0.24$ at $15^{\text {th }}$ day to $7.20 \pm 0.12$ at $35^{\text {th }}$ day.

The findings of instant investigation are in accordance with the work of Baldwinand Wood (2006). The sensory attributes were significantly enhanced with improved consumer acceptability. In another trial, Dang et al. (2008) observed that color changes were considerably controlled by coating application.

Table 7 Effects of edible coatings (treatments) and storage intervals on sensory scores for color of citrus

\begin{tabular}{lcccc}
\hline \multirow{2}{*}{ Treatments } & \multicolumn{3}{c}{ Storage } & \multirow{2}{*}{ Means (Treatments) } \\
\cline { 2 - 4 } & 15 days & 25 Days & 35 days & $6.33 \pm 0.16$ \\
\hline $\mathrm{T}_{0}$ & $8.30 \pm 0.23$ & $5.90 \pm 0.12$ & $4.80 \pm 0.13$ & $6.77 \pm 0.25$ \\
\hline $\mathrm{T}_{1}$ & $7.80 \pm 0.26$ & $6.70 \pm 0.34$ & $5.80 \pm 0.15$ & $7.10 \pm 0.21$ \\
\hline $\mathrm{T}_{2}$ & $8.40 \pm 0.30$ & $7.00 \pm 0.15$ & $5.90 \pm 0.18$ & $7.80 \pm 0.16$ \\
\hline $\mathrm{T}_{3}$ & $8.80 \pm 0.24$ & $7.40 \pm 0.13$ & $7.20 \pm 0.12$ & \\
\hline Means (Storage) & $8.33 \pm 0.26$ & $6.75 \pm 0.18$ & $5.93 \pm 0.14$ & \\
\hline $\mathrm{T} \cdot$ Control, $\mathrm{T}_{1}:(0.5 \%$
\end{tabular}

\section{Aroma}

It can be seen from (Table 8) regarding aroma of edible coated citrus that there was a systematic decline in the panelist ratings for the trait with the progress in storage. The maximum panelist scores were assigned to treatment $\mathrm{T}_{3}(2.0 \%$ cactus polysaccharides) as $7.83 \pm 0.19$ trailed by $\mathrm{T}_{2}(1.0 \%$ cactus polysaccharides $)$ and $\mathrm{T}_{1}(0.5 \%$ cactus polysaccharides $)$ as $7.17 \pm 0.17$ and $6.90 \pm 0.19$, respectively. Whilst $\mathrm{T}_{0}$ (Control) was assigned a score of $6.30 \pm 0.17$. Moreover, a gradual decline was observed in the scores for the trait with the developments in storage with $\mathrm{T}_{0}$ differing from $8.00 \pm 0.20$ to $6.10 \pm 0.14$ and $4.80 \pm 0.18$ at $15^{\text {th }}, 25^{\text {th }}$ and $35^{\text {th }}$ day, respectively. Similarly, for $\mathrm{T}_{1}$ andT $\mathrm{T}_{2}$ panelist ratings for the trait were reported to lower from $8.30 \pm 0.11$ to $5.60 \pm 0.31$ and $8.30 \pm 0.19$ to $5.80 \pm 0.09$ at $15^{\text {th }}$ to $35^{\text {th }}$ day, respectively. For treatment $\mathrm{T}_{3}$, panelist ratings declined from $8.70 \pm 0.13$ at $15^{\text {th }}$ day to $7.10 \pm 0.21$ at $35^{\text {th }}$ day. The findings are in accordance with the work of Baldwin (2000)

Table 8 Effects of edible coatings (treatments) and storage intervals on sensory scores for aroma of citrus

\begin{tabular}{lcccc}
\hline \multirow{2}{*}{ Treatments } & \multicolumn{3}{c}{ Storage } & \multirow{2}{*}{ Means (Treatments) } \\
\cline { 2 - 4 } & 15 days & 25 Days & 35 days & \\
\hline $\mathrm{T}_{0}$ & $8.00 \pm 0.20$ & $6.10 \pm 0.14$ & $4.80 \pm 0.18$ & $6.30 \pm 0.17 \mathrm{~d}$ \\
\hline $\mathrm{T}_{1}$ & $8.30 \pm 0.11$ & $6.80 \pm 0.16$ & $5.60 \pm 0.31$ & $6.90 \pm 0.19 \mathrm{c}$ \\
\hline $\mathrm{T}_{2}$ & $8.30 \pm 0.19$ & $7.40 \pm 0.24$ & $5.80 \pm 0.09$ & $7.17 \pm 0.17 \mathrm{~b}$ \\
\hline $\mathrm{T}_{3}$ & $8.70 \pm 0.13$ & $7.70 \pm 0.24$ & $7.10 \pm 0.21$ & $7.83 \pm 0.19 \mathrm{a}$ \\
\hline Means (Storage) & $8.33 \pm 0.16 \mathrm{a}$ & $7.00 \pm 0.19 \mathrm{~b}$ & $5.83 \pm 0.19 \mathrm{c}$ & \\
\hline $\mathrm{T}_{0} \cdot$ Control, $\mathrm{T}_{1}:(0.5 \%$ & $\mathrm{i}$ & \\
\hline
\end{tabular}

\section{Texture}

Mean values regarding texture of edible coated citrus (Table 9) revealed that there was a systematic decline in the panelist ratings with the progress in storage. The maximum panelist scores were assigned to treatment $\mathrm{T}_{3}(2.0 \%$ cactus polysaccharides $)$ as $7.83 \pm 0.17$ trailed by $\mathrm{T}_{2}(1.0 \%$ cactus polysaccharides $)$ and $\mathrm{T}_{1}$ ( $0.5 \%$ cactus polysaccharides) as $7.17 \pm 0.19$ and $6.83 \pm 0.19$, respectively. Whils $\mathrm{T}_{0}$ (Control) was at par with a score of $6.32 \pm 0.15$. Moreover, there was observed a gradual decline in the scores for the trait with the developments in storage with
$\mathrm{T}_{0}$ differing from $8.30 \pm 0.18$ to $6.15 \pm 0.18$ and $4.50 \pm 0.10$ at $15^{\text {th }}, 25^{\text {th }}$ and $35^{\text {th }}$ day, respectively. Likewise, for $\mathrm{T}_{1}$ and $\mathrm{T}_{2}$ panelist ratings for the trait were reported to lower from $8.00 \pm 0.21$ to $5.90 \pm 0.19$ and $8.50 \pm 0.17$ to $5.90 \pm 0.08$ at $15^{\text {th }}$ to $35^{\text {th }}$ day, respectively. For treatment $\mathrm{T}_{3}$, panelist ratings lowered from $8.60 \pm 0.25$ at $15^{\text {th }}$ day to $7.20 \pm 0.16$ at $35^{\text {th }}$ day.

The findings of instant investigation are in accordance with the work of Shahid and Abbasi (2011). The sensory attributes were significantly enhanced with improved consumer acceptability.

$\underline{\text { Table } 9 \text { Effects of edible coatings (treatments) and storage intervals on sensory scores for texture of citrus }}$

\begin{tabular}{|c|c|c|c|c|}
\hline \multirow{2}{*}{ Treatments } & \multicolumn{3}{|c|}{ Storage } & \multirow{2}{*}{ Means (Treatments) } \\
\hline & 15 days & 25 Days & 35 days & \\
\hline $\mathrm{T}_{0}$ & $8.30 \pm 0.18$ & $6.15 \pm 0.18$ & $4.50 \pm 0.10$ & $6.32 \pm 0.15 \mathrm{~d}$ \\
\hline $\mathrm{T}_{1}$ & $8.00 \pm 0.21$ & $6.60 \pm 0.16$ & $5.90 \pm 0.19$ & $6.83 \pm 0.19 \mathrm{c}$ \\
\hline $\mathrm{T}_{2}$ & $8.50 \pm 0.17$ & $7.10 \pm 0.31$ & $5.90 \pm 0.08$ & $7.17 \pm 0.19 \mathrm{~b}$ \\
\hline $\mathrm{T}_{3}$ & $8.60 \pm 0.25$ & $7.70 \pm 0.09$ & $7.20 \pm 0.16$ & $7.83 \pm 0.17 \mathrm{a}$ \\
\hline Means (Storage) & $8.35 \pm 0.20 \mathrm{a}$ & $6.89 \pm 0.18 b$ & $5.88 \pm 0.13 \mathrm{c}$ & \\
\hline
\end{tabular}

Taste

Means regarding taste of edible coated citrus (Table 10) showed that maximum hedonic scores were assigned to $\mathrm{T}_{3}(2.0 \%$ cactus polysaccharides $)$ as $7.83 \pm 0.17$ trailed by $\mathrm{T}_{2}(1.0 \%$ cactus polysaccharides $)$ and $\mathrm{T}_{1}(0.5 \%$ cactus polysaccharides $)$ as $7.17 \pm 0.19$ and $6.83 \pm 0.19$, respectively. However, lowest sensory scores was attained by $\mathrm{T}_{0}$ (control) as $6.32 \pm 0.15$. With the developments in storage, there was noticed a gradual decline in panelist preferences. It can be noticed that the maximum decline in sensory score was noted for $\mathrm{T}_{0}$ as scores lowered from
$8.30 \pm 0.18$ and $6.15 \pm 0.18$ to $4.50 \pm 0.10$ at $15^{\text {th }}, 25^{\text {th }}$ and $35^{\text {th }}$ day, respectively. However, amongst treatments $\mathrm{T}_{3}$ served as the most effective as it restricted the scores to $7.20 \pm 0.16$ at the termination of 21 days study. Likewise, for treatments $\mathrm{T}_{1}$ and $\mathrm{T}_{2}$, hedonic scores were found to lower from $8.00 \pm 0.21$ and $6.60 \pm 0.16$ to $5.90 \pm 0.19$ and $8.50 \pm 0.17,7.10 \pm 0.31$ to $5.90 \pm 0.08$ at $15^{\text {th }}, 25^{\text {th }}$ and $35^{\text {th }}$ day, respectively.

The findings of instant investigation are in harmony with the work of Ribeiro $\boldsymbol{e}$ al. (2007), who developed polysaccharide-based coatings to extend the shelf life of citrus. Likewise, Benítez et al. (2013) deduced that polysaccharides based 
coatings were instrumental in retaining color, firmness and improved acceptability of fruits.

Table 10 Effects of edible coatings (treatments) and storage intervals on sensory scores for taste of citrus

\begin{tabular}{lcccc}
\hline \multirow{2}{*}{ Treatments } & \multicolumn{3}{c}{ Storage } & \multirow{2}{*}{ Means (Treatments) } \\
\cline { 2 - 4 } & $\mathbf{1 5}$ days & $\mathbf{2 5}$ days & 35 days & \\
\hline $\mathrm{T}_{0}$ & $7.90 \pm 0.06$ & $5.90 \pm 0.17$ & $4.60 \pm 0.14$ & $6.13 \pm 0.12$ \\
\hline $\mathrm{T}_{1}$ & $8.00 \pm 0.27$ & $6.60 \pm 0.06$ & $5.70 \pm 0.23$ & $6.77 \pm 0.19$ \\
\hline $\mathrm{T}_{2}$ & $8.20 \pm 0.18$ & $7.10 \pm 0.15$ & $5.80 \pm 0.30$ & $7.03 \pm 0.21$ \\
\hline $\mathrm{T}_{3}$ & $8.40 \pm 0.16$ & $7.40 \pm 0.12$ & $6.90 \pm 0.28$ & $7.57 \pm 0.19$ \\
\hline Means (Storage) & $8.13 \pm 0.17$ & $6.75 \pm 0.12$ & $5.75 \pm 0.24$ & \\
\hline $\mathrm{T}$ Cannnnnn
\end{tabular}

$\mathrm{T}_{0}$ : Control, $\mathrm{T}_{1}:\left(0.5 \%\right.$ cactus polysaccharides), $\mathrm{T}_{2}:$ (1.0\% cactus polysaccharides), $\mathrm{T}_{3}:(2.0 \%$ cactus polysaccharides $)$

\section{Appearance}

It is clear from mean values for appearance of coated citrus (Table 11) that a pertinent decline in the panelist ratings for the trait was noticed. The maximum hedonic scores were $7.57 \pm 0.19$ for $\mathrm{T}_{3}$ (2.0\% cactus polysaccharides) trailed by $7.03 \pm 0.21$ and $6.77 \pm 0.19$ for $\mathrm{T}_{2}\left(1.0 \%\right.$ cactus polysaccharides) and $\mathrm{T}_{1}(0.5 \%$ cactus polysaccharides), respectively. However, the lowest hedonic ratings were noted for $\mathrm{T}_{0}$ (Control) as $6.13 \pm 0.12$. With the development in storage, it was observed that panelist preferences showed a steady decline ranging from $8.00 \pm 0.27$ to $6.60 \pm 0.06$ and $5.70 \pm 0.23$ at $7^{\text {th }}, 14^{\text {th }}$ and $21^{\text {st }}$ day for $\mathrm{T}_{1}(0.5 \%$ cactus polysaccharides), respectively. Likewise, panelist ratings for treatments $\mathrm{T}_{2}(1.0 \%$ cactus polysaccharides) and $\mathrm{T}_{3}$ (2.0\% cactus polysaccharides) lowered from $8.20 \pm 0.18$ and $8.40 \pm 0.16$ at initiation to $7.10 \pm 0.15$ and $7.40 \pm 0.12$ at $14^{\text {th }}$ day, respectively. Furthermore, at the end of the study sensory scores were recorded as $5.80 \pm 0.30$ and $6.90 \pm 0.28$ for respective treatments, respectively. The lowest panelist scores were assigned to $\mathrm{T}_{0}$ as it differed from $7.90 \pm 0.06$ and $5.90 \pm 0.17$ to $4.60 \pm 0.14$ at $7^{\text {th }}$ to $21^{\text {st }}$ day, respectively.

Our findings are in harmony with the work of Hassan et al., (2014). Similarly, Elizabeth (2006) concluded that coating application led to increased consumer acceptability due to its natural freshness and shine.

Table11 Effects of edible coatings (treatments) and storage intervals on sensory scores for appearance of citrus

\begin{tabular}{lcccc}
\hline \multirow{2}{*}{ Treatments } & \multicolumn{3}{c}{ Storage } & \multirow{2}{*}{ Means (Treatments) } \\
\cline { 2 - 4 } $\mathrm{T}_{0}$ & $\mathbf{1 5}$ days & 25 Days & 35 days & \\
\hline $\mathrm{T}_{1}$ & $8.90 \pm 0.06$ & $5.90 \pm 0.17$ & $4.60 \pm 0.14$ & $6.13 \pm 0.12$ \\
\hline $\mathrm{T}_{2}$ & $8.00 \pm 0.27$ & $6.60 \pm 0.06$ & $5.70 \pm 0.23$ & $6.77 \pm 0.19$ \\
\hline $\mathrm{T}_{3}$ & $8.40 \pm 0.18$ & $7.10 \pm 0.15$ & $5.80 \pm 0.30$ & $7.03 \pm 0.21$ \\
\hline Means (Storage) & $8.13 \pm 0.17$ & $7.40 \pm 0.12$ & $6.90 \pm 0.28$ & $7.57 \pm 0.19$ \\
\hline $\mathrm{T}_{0}:$ Control, $\mathrm{T}_{1}:\left(0.5 \%\right.$ cactus polysaccharides), $\mathrm{T}_{2}:\left(1.0 \%\right.$ cactus polysaccharides), $\mathrm{T}_{3}:(2.0 \%$ cactus polysaccharides) &
\end{tabular}

\section{Firmness}

It can be seen from Table 12 regarding firmness of coated citrus that a pertinent decline in the panelist ratings for the trait was noticed. It can be seen that maximum hedonic scores were $7.57 \pm 0.19$ for $\mathrm{T}_{3}(2.0 \%$ cactus polysaccharides $)$ trailed by $7.03 \pm 0.21$ and6.77 \pm 0.19 for $\mathrm{T}_{2}(1.0 \%$ cactus polysaccharides $)$ and $\mathrm{T}$ $(0.5 \%$ cactus polysaccharides), respectively. However, the lowest hedonic ratings were noted for $\mathrm{T}_{0}$ (Control) as $6.13 \pm 0.12$. With the development in storage, it was observed that panelist preferences showed a steady decline ranging from $8.00 \pm 0.27$ to $6.60 \pm 0.06$ and $5.70 \pm 0.23$ at $15^{\text {th }}, 25^{\text {th }}$ and $35^{\text {th }}$ day for $\mathrm{T}_{1}(0.5 \%$ cactus polysaccharides), respectively. Likewise, panelist ratings for treatments $\mathrm{T}_{2}$
( $1.0 \%$ cactus polysaccharides) and $\mathrm{T}_{3}(2.0 \%$ cactus polysaccharides)at initiation to $25^{\text {th }}$ day were $7.10 \pm 0.15$ and $7.40 \pm 0.12$, respectively. Furthermore, at the end of the study sensory scores were recorded as $5.80 \pm 0.30$ and6.90 \pm 0.28 for respective treatments, respectively. The lowest panelist scores were assigned to $\mathrm{T}_{0}$ as it differed from $7.90 \pm 0.06$ and $5.90 \pm 0.17$ to $4.60 \pm 0.14$ at $15^{\text {th }}$ to $35^{\text {th }}$ day, respectively.

Our findings are in harmony with the work of Hassan et al., (2014). They inferred that fruits treated with edible coatings had better firmness and appearance as compared to uncoated fruits.

Table 12 Effects of edible coatings (treatments) and storage intervals on sensory scores for firmness of citrus

\begin{tabular}{lcccc}
\hline \multirow{2}{*}{ Treatments } & \multicolumn{3}{c}{ Storage } & \multirow{2}{*}{ Means (Treatments) } \\
\cline { 2 - 4 } & $\mathbf{1 5}$ days & 25 days & 35 days & \\
\hline $\mathrm{T}_{0}$ & $8.20 \pm 0.19$ & $5.90 \pm 0.18$ & $4.50 \pm 0.18$ & $6.20 \pm 0.18$ \\
\hline $\mathrm{T}_{1}$ & $7.90 \pm 0.19$ & $6.70 \pm 0.17$ & $5.90 \pm 0.16$ & $6.83 \pm 0.18$ \\
\hline $\mathrm{T}_{2}$ & $8.10 \pm 0.21$ & $7.20 \pm 0.16$ & $6.80 \pm 0.16$ & $7.37 \pm 0.18$ \\
\hline $\mathrm{T}_{3}$ & $8.40 \pm 0.17$ & $7.40 \pm 0.20$ & $7.10 \pm 0.11$ & $7.63 \pm 0.16$ \\
\hline Means (Storage) & $8.15 \pm 0.19$ & $6.80 \pm 0.18$ & $6.08 \pm 0.15$ & \\
\hline $\mathrm{T}_{0}:$ Control, $\mathrm{T}_{1}:\left(0.5 \%\right.$ cactus polysaccharides), $\mathrm{T}_{2}:\left(1.0 \%\right.$ cactus polysaccharides), $\mathrm{T}_{3}:(2.0 \%$ cactus polysaccharides) &
\end{tabular}

\section{Shininess}

The shininess of edible coated citrus (Table 13) showed a systematic increase with increase in polysaccharides application, whilst shown the decreasing trend with increase in storage time. The maximum panelist scores were assigned to treatment $\mathrm{T}_{3}\left(2.0 \%\right.$ cactus polysaccharides) as $7.63 \pm 0.16$ trailed by $\mathrm{T}_{2}(1.0 \%$ cactus polysaccharides) and $\mathrm{T}_{1}(0.5 \%$ cactus polysaccharides $)$ as $7.37 \pm 0.18 \mathrm{and}$ $6.83 \pm 0.18$, respectively. Whilst $\mathrm{T}_{0}$ (Control) was at par with a score of $6.20 \pm 0.18$ Moreover, there was observed a gradual decline in the scores for the trait with the developments in storage with $\mathrm{T}_{0}$ differing from $8.20 \pm 0.19$ to $5.90 \pm 0.18$ and
$4.50 \pm 0.18$ at $15^{\text {th }}, 25^{\text {th }}$ and $35^{\text {th }}$ day, respectively. Likewise, for $\mathrm{T}_{1}$ and $\mathrm{T}_{2}$ panelist ratings for the trait were reported to lower from $7.90 \pm 0.19$ to $5.90 \pm 0.16$ and $8.10 \pm 0.21$ to $6.80 \pm 0.16$ at $15^{\text {th }}$ to $35^{\text {th }}$ day, respectively. For treatment $T_{3}$, panelist ratings lowered from $8.40 \pm 0.17$ at $15^{\text {th }}$ day to $7.10 \pm 0.11$ at $35^{\text {th }}$ day.

The findings of instant investigation are in accordance with the work of Moreira et al. (2011). The sensory attributes were significantly enhanced with improved consumer acceptability. In another trial, Hassan et al., (2014) studied hedonic response of edible coated citrus. They observed that shininess was considerably enhanced by coating application.

Table 13 Effects of edible coatings (treatments) and storage intervals on sensory scores for Shininess of citrus

\begin{tabular}{lcccc}
\hline \multirow{2}{*}{ Treatments } & \multicolumn{3}{c}{ Storage } & \multirow{2}{*}{ Means (Treatments) } \\
\cline { 2 - 4 } & 15 days & 25 Days & 35 days & \\
\hline $\mathrm{T}_{0}$ & $8.20 \pm 0.19$ & $5.90 \pm 0.18$ & $4.50 \pm 0.18$ & $6.20 \pm 0.18$ \\
\hline $\mathrm{T}_{1}$ & $7.90 \pm 0.19$ & $6.70 \pm 0.17$ & $5.90 \pm 0.16$ & $6.83 \pm 0.18$ \\
\hline $\mathrm{T}_{2}$ & $8.10 \pm 0.21$ & $7.20 \pm 0.16$ & $6.80 \pm 0.16$ & $7.37 \pm 0.18$ \\
\hline $\mathrm{T}_{3}$ & $8.40 \pm 0.17$ & $7.40 \pm 0.20$ & $7.10 \pm 0.11$ & $7.63 \pm 0.16$ \\
\hline Means (Storage) & $8.15 \pm 0.19$ & $6.80 \pm 0.18$ & $6.08 \pm 0.15$ & \\
\hline
\end{tabular}

$\mathrm{T}_{0}$ : Contro, $\mathrm{T}_{1}:$ ( $0.5 \%$ cactus polysaccharides), $\mathrm{T}_{2}:$ (1.0\% cactus polysaccharides), $\mathrm{T}_{3}:$ ( $2.0 \%$ cactuspolysaccharides) 


\section{Overall acceptability}

The overall acceptability of coated citrus (Table 14) showed a pertinent decline in the panelist ratings. The maximum hedonic scores were $7.57 \pm 0.17$ for $\mathrm{T}_{3}(2.0 \%$ cactus polysaccharides) trailed by $7.07 \pm 0.16$ and $6.70 \pm 0.21$ for $\mathrm{T}_{2}(1.0 \%$ cactus polysaccharides) and $\mathrm{T}_{1}(0.5 \%$ cactus polysaccharides $)$, respectively. However, the lowest hedonic ratings were noted for $\mathrm{T}_{0}$ (Control) as $5.97 \pm 0.12$. With the development in storage, it was observed that panelist preferences showed a steady decline ranging from $8.00 \pm 0.22$ to $6.90 \pm 0.13$ and $5.20 \pm 0.27$ at $15^{\text {th }}, 25^{\text {th }}$ and $35^{\text {th }}$ day for $\mathrm{T}_{1}(0.5 \%$ cactus polysaccharides $)$, respectively. Likewise, panelist ratings for treatments $\mathrm{T}_{2}(1.0 \%$ cactus polysaccharides $)$ and $\mathrm{T}_{3}(2.0 \%$ cactus polysaccharides) lowered from $8.20 \pm 0.16$ and $8.60 \pm 0.26$ at initiation to $7.20 \pm 0.19$ and $7.80 \pm 0.14$ at $25^{\text {th }}$ day, respectively. Furthermore, at the end of the study sensory scores were recorded as $5.80 \pm 0.13$ and $6.30 \pm 0.09$ for respective treatments, respectively. The panelist scores assigned to $\mathrm{T}_{0}$ differed from $8.10 \pm 0.06$ and $5.80 \pm 0.14$ to $4.00 \pm 0.17$ at $15^{\text {th }}$ to $35^{\text {th }}$ day, respectively.

Our findings are in harmony with the work of Adetunji et al., (2012). Likewise, Shahid (2007) studied sensory response of various fruits after coatings application. It was concluded that coating application led to increased consumer acceptability.

Table 14 Effects of edible coatings (treatments) and storage intervals on sensory scores for overall acceptability of citrus

\begin{tabular}{lcccc}
\hline \multirow{2}{*}{ Treatments } & \multicolumn{3}{c}{ Storage } & Means (Treatments) \\
\cline { 2 - 4 } & 15 days & 25 Days & 35 days & $5.97 \pm 0.12 \mathrm{~d}$ \\
\hline $\mathrm{T}_{0}$ & $8.10 \pm 0.06$ & $5.80 \pm 0.14$ & $4.00 \pm 0.17$ & $6.70 \pm 0.21 \mathrm{c}$ \\
\hline $\mathrm{T}_{1}$ & $8.00 \pm 0.22$ & $6.90 \pm 0.13$ & $5.20 \pm 0.27$ & $7.07 \pm 0.16 \mathrm{~b}$ \\
\hline $\mathrm{T}_{2}$ & $8.20 \pm 0.16$ & $7.20 \pm 0.19$ & $5.80 \pm 0.13$ & $7.57 \pm 0.17 \mathrm{a}$ \\
\hline $\mathrm{T}_{3}$ & $8.60 \pm 0.26$ & $7.80 \pm 0.14$ & $6.30 \pm 0.09$ & \\
\hline Means (Storage) & $8.23 \pm 0.18 \mathrm{a}$ & $6.93 \pm 0.15 \mathrm{~b}$ & $5.33 \pm 0.16 \mathrm{c}$ & \\
\hline $\mathrm{T}_{0}:$ Control, $\mathrm{T}_{1}:\left(0.5 \%\right.$ cactus polysaccharides), $\mathrm{T}_{2}:\left(1.0 \%\right.$ cactus polysaccharides), $\mathrm{T}_{3}:(2.0 \%$ cactus polysaccharides $)$ &
\end{tabular}

\section{CONCLUSION}

Citrus fruits are subjected to extensive post-harvest losses due to high moisture content and other physiological factors. These losses can be minimized by adopting various strategies. Among these, application of edible coatings is gaining much popularity owing to their suitability to be utilized with fruit Polysaccharide extracted from indigenous sources like cactus can be used for the formulation of edible coatings which could play an imperative role in extending the shelf life of citrus. Moreover, the present research broadens the scope for utilization of wild plants with higher polysaccharides contents. The future aspects of the study involve the comparative analysis of edible coatings with commercially applied coatings in the industry.

\section{REFERENCES}

AACC. 2000. Approved Methods of American Association of Cereal Chemists. American Association of Cereal Chemist, Inc St Paul, MN, USA.

ABEER, H., ABD-ALLAH, E. F., AL-OBEED, R. S., MRIDHA, M. A. U., AL HUQAIL, A. A. 2013. Non-chemical strategies to control postharvest losses and extend the shelf life of table grape fruits. Biological Agriculture \& Horticulture, 29 (2), 82-90. https://doi.org/10.1080/01448765.2013.763735.

ADETUNJI C. O., FAWOLE O.B., AROWORA K.A., NWAUBANI S.I AJAYI E. S., OLOKE J. K., MAJOLAGBE O.M., OGUNDELE B. A., AINA J .A., ADETUNJI J .B. 2012. Effects of edible coatings from aloe vera gel on quality and postharvest physiology of AnanasComosus (L.) Fruit during ambient storage. Global Journal of Science Frontier Research, 12 (5), 39-43.

AL-JUHAIMI, F., GHAFOOR, K. A. S. H. I. F., BABIKER, E. E. 2012. Effect of gum arabic edible coating on weight loss, firmness and sensory characteristics of cucumber (Cucumissativus L.) fruit during storage. Pakistan Journal of Botany, 44 (4), 1439-1444.

BALDWIN, E.A., WOOD, B. 2006. Use of edible coating to preserve pecans at room temperature. Horticulture Science. 41 (1):188-192.

BENITEZ, S., I.ACHAERANDIO, F., SEPULCREAND M.P. 2013. Aloe vera based edible coatings improve the quality of minimally processed'Hayward' kiwifruit. Postharvest Biology and Technology, 81, 29-36. https://doi.org/10.1016/j.postharvbio.2013.02.009.

DANG, K.T.H., SINGH, Z., SWINNY, E.E. 2008. Edible coatings influence fruit ripening,quality, and aroma biosynthesis in mango fruit. J. Agric. Food Chemistry, 56, 1361-1370. https://doi.org/10.1021/jf072208a .

ECKERT, J. W., EAKS, I. L. 1989.Postharvest disorders and diseases of citrus fruits. The citrus industry, 5, 179-260.

FAN, W. J., SUN, J. X., CHEN, Y. C. 2009.Effects of chitosan coating on quality and shelf life of silver carp during frozen storage. Food Chemistry, 115, 66-70. https://doi.org/10.1016/j.foodchem.2008.11.060.

HASSAN, Z. H., LESMAYATI, S., QOMARIAH, R., HASBIANTO, A 2014.Effects of wax coating applications and storage temperatures on the quality of tangerine citrus (Citrus reticulata) var. Siam Banjar. International Food Research Journal,21 (2).

HODGES, R. J., BUZBY, J. C., BENNETT, B. 2011. Postharvest losses and waste in developed and less developed countries: opportunities to improve resource use. The Journal of Agricultural Science, 149 (S1), 37-45. https://doi.org/10.1017/s0021859610000936.

KIRK, R. S., SAWYER, R. 1991. Pearson's Composition and Analysis of Foods, 9th edn.Longman Scientific and Technical, Harlow, UK.

MEILGAARD, M.C., CIVILLE, G.V., CARR, B.T. 2007. Sensory Evaluation Techniques, 4th Ed. C.R.C. Press L.L.C., NY, USA.

MOHEBBI, M., AMIRYOUSEFI, M. R., HASANPOUR, N., ANSARIFAR, E. 2012. Employing an intelligence model and sensitivity analysis to investigate some physicochemical properties of coated bell pepper during storage.
International Journal of Food Science \& Technology, 47 (2), 299-305 https://doi.org/10.1111/j.1365-2621.2011.02839.x

Moreira, M.R., Roura, S.I., Ponce, A.2011. Effectiveness of chitosan edible coatingsto improve microbiological and sensory quality of fresh cut broccoli. LWT - Food Science Technology, 44, 2335-2341. https://doi.org/10.1016/j.lwt.2011.04.009.

MUSASA, S. T., MVUMI, B. M., MANDITSERA, F. A., CHINHANGA, J., MUSIYANDAKA, S., CHIGWEDERE, C. 2013. Postharvest orange losses and small-scale farmers' perceptions on the loss causes in the fruit value chain: a case study of Rusitu Valley, Zimbabwe. Food Science and Quality Management, 18 (2), 1-8.

RIBEIRO, C., VICENTE, A. A., TEIXEIRA, J. A., MIRANDA, C. 2007.Optimization of edible coating composition to retard strawberryfruit senescence. Postharvest Biology and Technology, 44, 63-70. https://doi.org/10.1016/j.postharvbio.2006.11.015.

SHAHID, M. N. 2007. Effect of bee wax coating on the organoleptic changes in fruit of sweet orange (Citrus sinensis L.) cv." blood red".Sarhad Journal of Agriculture, 23 (2), 411

SHAHID, M. N., ABBASI, N. A. (2011). Effect of beewax coatings on physiological changes in fruits of sweet orange CV."Blood Red".Sarhad Journal of Agriculture, 27 (3), 385-394.

STEEL, R.G.D., TORRIE, J.H., DICKEY, D. 1997. Principles and Procedures of Statistics: A Biometrical Approach. 3rd Ed. McGraw Hill Book Co Inc, NY, USA.

TAPIA, M.S., ROJAS-GRAU, M.A., CARMONA, A., RODRIGUEZ,F.J. SOLIVA-FORTUNY, R., MARTIN-BELLOSO, O.2008. Use of alginate- and gellan-based coatingsfor improving barrier, texture and nutritionalproperties of $\begin{array}{llll}\text { fresh-cut papaya. Food Hydrocolloids, } & 22, & 1493\end{array}$ 1503. https://doi.org/10.1016/j.foodhyd.2007.10.004

VARGAS, M., CHIRALT, A., ALBORS, A., \& GONZALEZ-MARTINEZ, C. 2009.vEffect of chitosan-based edible coatings applied by vacuum impregnation on quality preservation of fresh-cut carrot. Postharvest Biology and Technology, 51(2), 263-271. https://doi.org/10.1016/j.postharvbio.2008.07.019

VELICKOVA, E., WINKELHAUSEN, E., KUZMANOVA, S., ALVES, V. D. \&MOLDÃO-MARTINS, M. 2013. Impact of chitosan-beeswax edible coatings on the quality of fresh strawberries $(<\mathrm{i}>$ Fragariaananassa $</ \mathrm{i}>\mathrm{cvCamarosa})$ under commercial storage conditions. LWT-Food Science and Technology, 52(2), 8092. https://doi.org/10.1016/i.lwt.2013.02.004

Yahia, E. M., Barry-Ryan, C., Dris, R. 2004.Treatments and techniques to minimise the postharvest losses of perishable food crops. In: Production practices and quality assessment of food crops (pp. 95-133). Springer Netherlands. 